\title{
EFFECT OF MATURITY STAGE AND SHORT-TERM STORAGE ON THE BIOLOGICAL QUALITY OF SWEET PEPPER FRUITS
}

\author{
Anna KOŁTON, Renata WOJCIECHOWSKA, Maria LEJA \\ Department of Botany and Plant Physiology \\ University of Agriculture in Krakow, \\ al. 29 Listopada 54, 31-425 Krakow, Poland
}

Received: August 10, 2010; Accepted: January 30, 2011

\begin{abstract}
Summary
Sweet pepper plants of Spartacus cultivar were grown in plastic tunnel on rockwool using the fertigation technique. The three year experiment was carried out in 2006-2008. Fruits were harvested every year in three maturity stages: green, turning and red. The contents of ascorbic acid, phenols, soluble sugars, nitrate and ammonium ions, total nitrogen, free amino acids and dry matter were determined in freshly harvested fruits as well as after short-term (two weeks) storage.

Red pepper fruits accumulated significantly more ascorbic acid, soluble sugars and phenols in comparison with the green and turning ones. The level of nitrate ions was highest in the green fruits and decreased during their ripening while the ammonium ion concentration increased. The lowest content of amino acids was observed in green fruits.

Two week storage at $5-8^{\circ} \mathrm{C}$, followed by two days at room temperature caused the reduction of nitrate ions in green and red fruits. Ammonium ion content as well as phenol and soluble sugar level increased in stored fruits, irrespectively of their maturity stage. Ascorbic acid content increased in the stored turning and red pepper fruits as related to its initial concentration. Dry matter content did not change after storage. Biological quality of harvested pepper fruits depended of their maturity stage, however, their response to short-term storage was similar.
\end{abstract}

key words: pepper, fruits, maturity stage, ascorbic acid, phenols, nitrates, storage

\section{INTRODUCTION}

Sweet pepper fruits are rich in health-promoting compounds such as vitamins $(\mathrm{C}, \mathrm{A}, \mathrm{E}, \mathrm{B})$, soluble sugars, peptides, mineral constituents, carote- noids and phenols. Some of these substances are excellent antioxidants. Levels of these compounds are influenced by genotype, maturity stage, growing and post harvest conditions (Wien 1997, Howard et al. 2000,

Corresponding author: 
Wall et al. 2001). During fruit maturity its quality changes. Losses of chlorophylls and synthesis of carotenoids were observed (De Guevara et al. 1996, Simonne et al. 1997, Madrid et al. 1999) as well as accumulation of sugars. Red fruits usually accumulated more ascorbic acid than green ones (Golcz \& Kozik 2004). During maturation the color of pepper fruits changed and they lost their firmness, due to the increase of soluble pectins and decrease of cellulose content (Cheng et al. 2008). Spectral properties of sweet pepper fruits were accompanied by color changes of ripening fruits leading to the decrease of photosynthetic activity (Pilarski \& Kocurek 2005).

Storage ability of sweet pepper fruits is low and they are often infected by grey mould. Storage conditions influence chemical composition of pepper and also the quality of fruits. Appearance of chilling injury on fruits is observed at low temperature. Temperature lower than $8^{\circ} \mathrm{C}$ causes damage of green fruits but the red ones stay unaffected (Adamicki 2001, Kosson 2003). The recommended storage temperature for sweet pepper should be about $7-8^{\circ} \mathrm{C}$.

To prevent the weight losses of fruits storage in plastic bags is recommended (Adamicki 2001, Kosson \& Stępowska 2002). Storage conditions are especially important for ascorbic acid concentration, considerable losses of this compound were often observed during storage of pepper (Lee \& Kader 2000, Biniek 1995).

The aim of present study was to evaluate the effect of maturity stage and short time storage on selected compounds in pepper fruits.

\section{MATERIALS AND METHODS}

Sweet pepper (Capsicum annuum L. 'Spartacus', De Ruiter Seeds) was grown on rockwool using fertigation technique in plastic tunnel $50 \times 9$ $\mathrm{m}$ dimension. The experiment was carried out every year in 2006-2008. Mineral nutrients were introduced in the concentration recommended for pepper cultivation. Fruits of sweet pepper were harvested at three maturity stages: mature green, turning $(50 \%$ or more of fruit surface changed color to reddish-brown) and red (fully ripe). Fruits were harvested from third and fourth internod level every year at the beginning of July. Thirty fruits of each maturity stage were harvested and divided into two groups. The first one was analyzed just after harvest and the second was stored. Fruits were stored in perforated plastic bags in a cold chamber at $5-8^{\circ} \mathrm{C}$ and 80 $85 \%$ relative humidity for two weeks followed by two days at $22^{\circ} \mathrm{C}$. After storage no chilling injury was observed and turning fruits in most cases changed color to red.

The blended flesh material was used for chemical analysis. Ascorbic acid content was determined by iodate titration method (Duliński et al. 1988), total phenols were measured by photometric method with Folin's reagent (Swain \& Hillis 1959), soluble sugars by method with anthron reagent (Yemm \& Wills 1954). Nitrate and ammonium ions were detected using ionometer Orion 920A+. Total nitrogen was estimated according to the Kjeldahl method, free amino acids were detected by method with ninhydrin reagent (Korenman 
1973). For determination of dry matter plant material was dried at $105^{\circ} \mathrm{C}$.

All analyses were made in three replications. Results were statistically evaluated using ANOVA and Fisher (LSD) test for the significance $\mathrm{P}=0.05$. Homogenous groups are represented by the same letters. The Pearson's correlation coefficient was calculated for analyzed parameters for the significance $\mathrm{P}=0.05$.

\section{RESULTS}

During the ripening of fruits their color changed from green to red. The lowest and the highest concentration of nitrate ions was determined in red and green fruits, respectively, while the turning fruits accumulated less nitrate ions than green ones (see the three year averages in Table 1). This tendency was observed in 2007 and 2008, while during 2006 red and turning fruits accumulated similar concentration of nitrate ions. The level of ammonium ions was lowest in green fruits and increased during ripening in 2007 and 2008. Only in 2006 the level of ammonium ions in green and red fruits was similar. Content of free amino acids was lowest in green peppers and increased in turning and red ones in all growing seasons. The concentration of total nitrogen changed during ripening, the same level of nitrogen was observed in green and red fruits, however, significantly lower in the turning ones (three year means). The lowest content of nitrogen was found in turning and green fruits in 2007 and 2008, respectively. The content of phenols, ascorbic acid, soluble sugars and dry matter increased during the maturation of fruits, in most cases significantly (Table 2).

Table 1. Concentration of nitrate $\left(\mathrm{mg} \mathrm{NO}_{3}{ }^{-} \cdot \mathrm{kg}^{-1}\right.$ f.w.) and ammonium $\left(\mathrm{mg} \mathrm{NH}_{4}{ }^{+} \cdot \mathrm{kg}^{-1}\right.$ f.w) ions, free amino acids (mg N $100 \mathrm{~g}^{-1} \mathrm{f}$.w) and total nitrogen $\left(\mathrm{g} \mathrm{N} \cdot 100 \mathrm{~g}^{-1}\right.$ d.m.) in sweet pepper fruits at three maturity stages

\begin{tabular}{lcccccccc}
\hline \multicolumn{1}{c}{$\begin{array}{c}\text { Fruit } \\
\text { maturity } \\
\text { stage }\end{array}$} & mean & 2006 & 2007 & 2008 & mean & 2006 & 2007 & 2008 \\
\cline { 2 - 8 } & $77.46 \mathrm{c}^{*}$ & $87.32 \mathrm{~b}$ & $70.34 \mathrm{c}$ & $74.71 \mathrm{c}$ & $212.6 \mathrm{a}$ & $265.6 \mathrm{~b}$ & $190.8 \mathrm{a}$ & $181.4 \mathrm{a}$ \\
\hline Green & $52.33 \mathrm{~b}$ & $48.78 \mathrm{a}$ & $51.28 \mathrm{~b}$ & $56.92 \mathrm{~b}$ & $246.4 \mathrm{~b}$ & $195.4 \mathrm{a}$ & $280.1 \mathrm{~b}$ & $263.7 \mathrm{~b}$ \\
Turning & $48.95 \mathrm{a}$ & $48.60 \mathrm{a}$ & $47.07 \mathrm{a}$ & $51.19 \mathrm{a}$ & $343.1 \mathrm{c}$ & $251.1 \mathrm{~b}$ & $385.8 \mathrm{c}$ & $392.4 \mathrm{c}$ \\
Red & \multicolumn{4}{c}{ Free amino acids } & & \multicolumn{4}{c}{ Total nitrogen } \\
\hline & mean & 2006 & 2007 & 2008 & mean & 2006 & 2007 & 2008 \\
\hline Green & $26.21 \mathrm{a}$ & $21.34 \mathrm{a}$ & $36.13 \mathrm{a}$ & $21.13 \mathrm{a}$ & $2.59 \mathrm{~b}$ & $-* *$ & $2.98 \mathrm{c}$ & $2.19 \mathrm{a}$ \\
Turning & $43.16 \mathrm{~b}$ & $56.89 \mathrm{c}$ & $43.52 \mathrm{~b}$ & $29.13 \mathrm{~b}$ & $2.36 \mathrm{a}$ & - & $2.30 \mathrm{a}$ & $2.42 \mathrm{~b}$ \\
Red & $42.28 \mathrm{~b}$ & $46.12 \mathrm{~b}$ & $48.79 \mathrm{c}$ & $31.94 \mathrm{c}$ & $2.66 \mathrm{~b}$ & - & $2.73 \mathrm{~b}$ & $2.58 \mathrm{~b}$ \\
\hline
\end{tabular}

* statistical analysis was done separately for every year and for individual parameters

** total nitrogen was not measured in 2006 
Table 2. Concentration of phenols (mg $\left.\cdot 100 \mathrm{~g}^{-1} \mathrm{f} . \mathrm{w}.\right)$, ascorbic acid (mg $\cdot 100 \mathrm{~g}^{-1} \mathrm{f} . \mathrm{w}$. ), soluble sugars (\% of fresh weight) and dry matter $(\%)$ in sweet pepper fruits at three maturity stages

\begin{tabular}{|c|c|c|c|c|c|c|c|c|}
\hline \multirow{2}{*}{$\begin{array}{c}\text { Fruit } \\
\text { maturity } \\
\text { stage }\end{array}$} & \multicolumn{4}{|c|}{ Phenols } & \multicolumn{4}{|c|}{ Ascorbic acid } \\
\hline & mean & 2006 & 2007 & 2008 & mean & 2006 & 2007 & 2008 \\
\hline Green & $35.77 \mathrm{a} *$ & $32.47 \mathrm{a}$ & $35.26 \mathrm{a}$ & $39.57 \mathrm{a}$ & $141.7 \mathrm{a}$ & $120.7 \mathrm{a}$ & $164.6 \mathrm{a}$ & $139.9 \mathrm{a}$ \\
\hline Turning & $42.90 \mathrm{~b}$ & $35.58 \mathrm{~b}$ & $45.24 \mathrm{~b}$ & $47.87 \mathrm{~b}$ & $169.0 \mathrm{~b}$ & $176.4 \mathrm{~b}$ & $167.2 \mathrm{a}$ & $163.5 \mathrm{~b}$ \\
\hline \multirow[t]{3}{*}{ Red } & $56.44 \mathrm{c}$ & $53.06 \mathrm{c}$ & $53.31 \mathrm{c}$ & $62.95 \mathrm{c}$ & $186.4 \mathrm{c}$ & $194.5 \mathrm{c}$ & $192.4 \mathrm{~b}$ & $172.3 \mathrm{c}$ \\
\hline & \multicolumn{4}{|c|}{ Soluble sugars } & \multicolumn{4}{|c|}{ Dry matter } \\
\hline & mean & 2006 & 2007 & 2008 & mean & 2006 & 2007 & 2008 \\
\hline Green & $3.346 \mathrm{a}$ & $3.523 \mathrm{a}$ & $4.232 \mathrm{a}$ & $2.284 \mathrm{a}$ & $7.37 \mathrm{a}$ & $6.52 \mathrm{a}$ & $9.02 \mathrm{a}$ & $6.56 \mathrm{a}$ \\
\hline Turning & $4.430 \mathrm{~b}$ & $4.295 \mathrm{~b}$ & $5.552 \mathrm{~b}$ & $3.445 \mathrm{~b}$ & $8.94 \mathrm{~b}$ & $8.75 \mathrm{~b}$ & $9.13 \mathrm{a}$ & $8.94 \mathrm{~b}$ \\
\hline Red & $5.773 \mathrm{c}$ & $5.997 \mathrm{c}$ & $6.880 \mathrm{c}$ & $4.442 \mathrm{c}$ & $9.64 \mathrm{~b}$ & $9.55 \mathrm{c}$ & $10.22 \mathrm{a}$ & $9.15 \mathrm{~b}$ \\
\hline
\end{tabular}

* statistical analysis was done separately for every year and for individual parameters

In the case of storage only results which are means from three years study are presented in this paper. The concentration of nitrate ions decreased but ammonium ions increased in green and red fruits during storage (Fig. 1, 3). In the case of turning ones content of nitrate ions before and after storage was the same, however, concentration of ammonium ions increased (Fig. 2). Level of free amino acids in green and red fruits did not differ before and after storage but in turning ones increased. In freshly harvested fruits content of nitrogen was lower in green and turning fruits than after storage but it did not change in the stored fruits of full maturity. Increase of phenols and soluble sugars content during storage was noticed in all the three maturity stages, however, just in the case of turning and red fruits ascorbic acid accumulation was observed. Ascorbic acid concentration did not change during storage in green pepper fruits as well as dry matter content in fruits of all the three maturity stages.

The significant correlation was found between the concentration of soluble sugars and amino acids $(r=0.70)$, ascorbic acid $(r=0.72)$ and dry matter $(r=0.53)$. Between nitrate and ammonium ions content negative correlation was found $(\mathrm{r}=-0.38)$. There was also a significant correlation between free amino acids content and nitrogen concentration in pepper fruits $(r=0.41)$. 


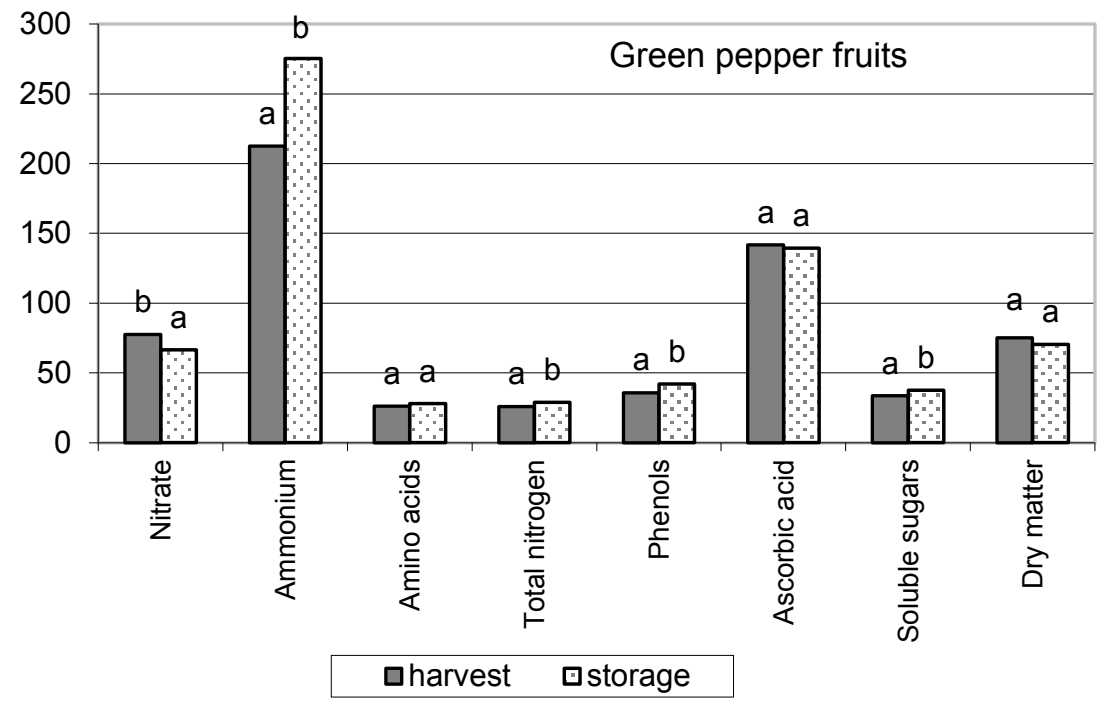

Fig. 1. Concentration of nitrate $\left(\mathrm{mg} \mathrm{NO}_{3}^{-} \cdot \mathrm{kg}^{-1}\right.$ f.w.) and ammonium $\left(\mathrm{mg} \mathrm{NH}_{4}^{+} \cdot \mathrm{kg}^{-1}\right.$ f.w) ions, free amino acids ( $\left.\mathrm{mg} \mathrm{N} \cdot 100 \mathrm{~g}^{-1} \mathrm{f} . \mathrm{w}\right)$, total nitrogen $\left(\mathrm{g} \mathrm{N} \cdot \mathrm{kg}^{-1} \mathrm{~d} . \mathrm{m}\right.$.) phenols $\left(\mathrm{mg} \cdot 100 \mathrm{~g}^{-1}\right.$ f.w.), ascorbic acid (mg·100 $\mathrm{g}^{-1}$ f.w.), soluble sugars $\left(\mathrm{g} \cdot \mathrm{kg}^{-1} \mathrm{f} . \mathrm{w}.\right)$ and dry matter $\left(\mathrm{g}^{\mathrm{kg}} \mathrm{kg}^{-1}\right.$ f.w.) in green pepper fruits before and after storage (means for three year experiment)

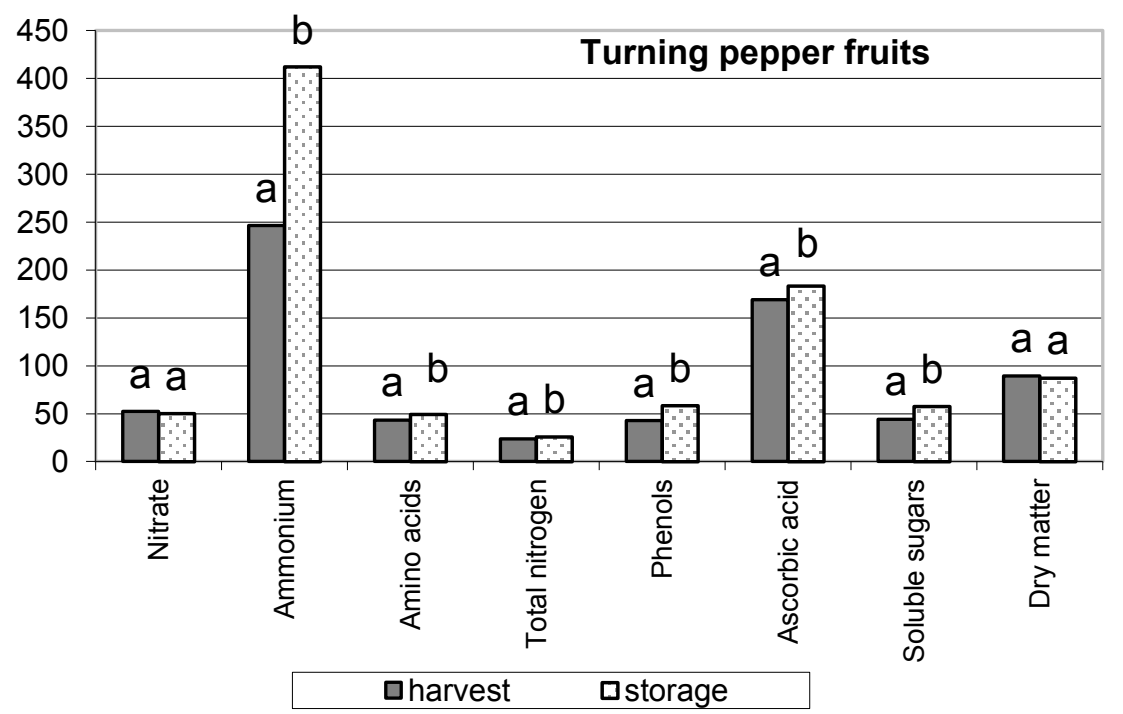

Fig. 2. Concentration of nitrate $\left(\mathrm{mg} \mathrm{NO}_{3}^{-} \cdot \mathrm{kg}^{-1}\right.$ f.w.) and ammonium $\left(\mathrm{mg} \mathrm{NH}_{4}^{+} \cdot \mathrm{kg}^{-1}\right.$ f.w $)$ ions, free amino acids (mg N $\left.100 \mathrm{~g}^{-1} \mathrm{f} . \mathrm{w}\right)$, total nitrogen $\left(\mathrm{g} \mathrm{N} \cdot \mathrm{kg}^{-1} \mathrm{~d} . \mathrm{m}\right.$.) phenols $\left(\mathrm{mg} \cdot 100 \mathrm{~g}^{-1}\right.$ f.w.), ascorbic acid (mg.100 $\mathrm{g}^{-1}$ f.w.), soluble sugars (g・ $\mathrm{kg}^{-1}$ f.w.) and dry matter $\left(\mathrm{g} \cdot \mathrm{kg}^{-1}\right.$ f.w.) in turning pepper fruits before and after storage (means for three year experiment). 


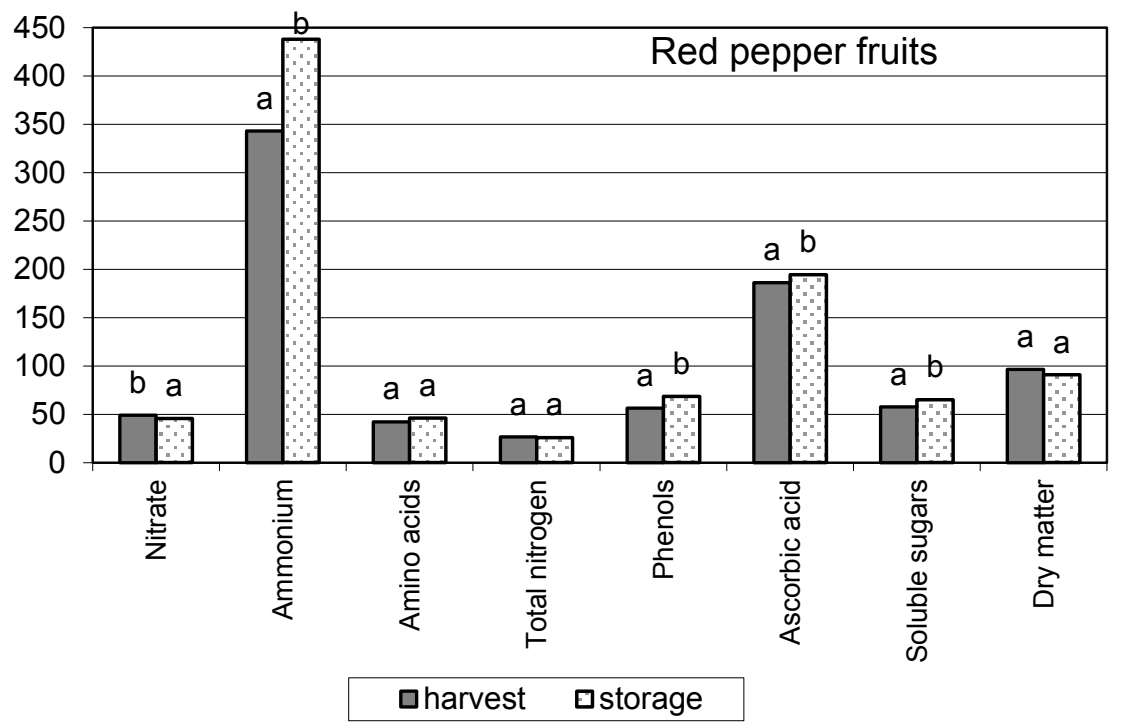

Fig. 3. Concentration of nitrate $\left(\mathrm{mg} \mathrm{NO}_{3}^{-} \cdot \mathrm{kg}^{-1}\right.$ f.w.) and ammonium $\left(\mathrm{mg} \mathrm{NH}_{4}^{+} \cdot \mathrm{kg}^{-1}\right.$ f.w $)$ ions, free amino acids (mg N$\left.\cdot 100 \mathrm{~g}^{-1} \mathrm{f} . \mathrm{w}\right)$, total nitrogen $\left(\mathrm{g} \mathrm{N} \cdot \mathrm{kg}^{-1} \mathrm{~d} . \mathrm{m}\right.$.) phenols $\left(\mathrm{mg} \cdot 100 \mathrm{~g}^{-1}\right.$ f.w.), ascorbic acid (mg·100 $\mathrm{g}^{-1}$ f.w.), soluble sugars $\left(\mathrm{g} \cdot \mathrm{kg}^{-1} \mathrm{f} . \mathrm{w}.\right)$ and dry matter $\left(\mathrm{g} \cdot \mathrm{kg}^{-1} \mathrm{f} . \mathrm{w}\right.$.) in red pepper fruits before and after storage (means for three year experiment)

\section{DISCUSSION}

Ripening of sweet pepper fruits is correlated with many biochemical changes. Perucka (2004) observed increase of carotenoids and dry matter content during pepper fruits ripening. Similarly, dry matter content in the present study in green fruits was lowest. Increase of dry matter as well as ascorbic acid, fructose and glucose concentrations in pepper fruits was reported by Navarro et al. (2006). Phenols content, however, was maintained in ripening pepper. In the present research accumulation of ascorbic acid, phenols and soluble sugars was observed during pepper fruits maturation. These results confirm previous studies concerning the increase of phenolic acids content and flavonoids concentration during pepper fruits ripening (Howard et al.
2000). Some other authors observed similar biochemical changes during maturation (Tadesse et al. 2002), however, high level of phenols in green fruits and their reduction during ripening was described by Conforti $e t$ al. (2007).

It is important to notice that in all the cases concentration of nitrate was at the acceptable level. Concentration of nitrate ions in vegetables depends on maturity stage (Lisiewska \& Kmiecik 1991a) as was observed also in the examined pepper fruits. Content of nitrogen in the tested pepper fruits was independent on maturity stage (average $2.54 \%$ of dry matter) and was lower than that observed by Bugarski et al. (2007) (average 3.35\% of dry matter) in nine pepper cultivars.

Information about ascorbic acid concentration during the storage of pepper fruits varies, some authors 
reported decrease of that compound (Biniek \& Sas-Golak 1998), according to the others the level of ascorbic acid increased (Simonne et al. 1997). Kosson and Stępowska $(2005,2006)$ noticed that ascorbic acid content during storage depended on the year of growing, growing conditions, variety and other factors. In the case of 'Spartacus' pepper accumulation of this vitamin depended on maturity stage, in turning and red fruits increased during storage.

In the present experiment the maintained level of dry matter in pepper fruits before and after storage was probably caused by good conditions in cold chamber and short term of storage. A great number of authors reported the increase of dry matter during storage due to high water losses (Biniek \& Sas-Golak 1998, Kosson \& Stępowska 2002, 2005, 2006). Decrease of nitrate ions and increase of ammonium ions in pepper fruits during storage suggest that nitrate level was reduced during keeping fruits in cold chamber. These results were consistent with the other studies (Lisiewska \& Kmiecik 1991b).

Leja et al. (1998) reported increase of phenols during the storage of vegetables. This was also observed in the present study with pepper fruits as well as the increase of soluble sugars. Accumulation of soluble sugars affected by storage was also observed in pumpkin, however, reduction of these compounds in carrot and red beet was noticed by Autko et al. (2005).

The presented results suggest that conditions in cold store $\left(5-8^{\circ} \mathrm{C}\right.$ and $80-85 \%$ relative humidity, storage in perforated plastic bags) limited respiration and prevented weight loss- es as well as reduction of fruit quality. Pepper fruit, independently of their maturity stage, remained in good quality after two-week storage.

\section{CONCLUSIONS}

1. The highest content of healthy promoting compounds such ascorbic acid and phenols accumulated red pepper fruits in comparison to green and turning ones.

2. Maturation of pepper fruits as well as their storage was accompanied by reduction of nitrate ions and by increase of ammonium ions.

3. In stored pepper fruits losses of dry matter and ascorbic acid were not observed, the increase in soluble sugars and phenols concentration was noted.

\section{Acknowledgement}

The study was financed by the State Committee for Scientific Research in Poland, under project No. 2P06R 02130

This work was supported under "InnoGrant- the innovation activities of postgraduate students supporting programme".

\section{REFERENCES}

Adamicki F. 2001. Wpływ zmodyfikowanej i kontrolowanej atmosfery na przedłużenie pozbiorczego składowania papryki. Zeszyty Naukowe ATR w Bydgoszczy 234 Rolnictwo 46: 13-19. [in Polish]

Autko A.A., Rupasowa Zh.A., Autko An.A., Poznyak O.V. 2005. Change in the contenst of useful substances in vegetables during storage. Sodininkyste ir Daržininkyste 24(3): 411-420.

Biniek A. 1995. Wpływ metod przechowywania na jakość owoców papryki słodkiej. Fizjologiczne aspekty pro- 
dukcji ogrodniczej, Ogólnopolska Konferencja Naukowo-Techniczna, Kraków 30 listopada 1995: 111-113. [in Polish]

Biniek A., Sas-Golak I. 1998. Przechowywanie a jakość owoców papryki słodkiej pochodzących z upraw na wełnie mineralnej. Zesz. Nauk. AR w Krakowie 333(57): 53-57. [in Polish]

Bugarski D., Gvozdenović Dj., Červenski J. 2007. Macro-elements in pepper fruits. Acta Hort. 729: 193-197.

Cheng J., Shen H., Yang X., Yu S., Yuan L., Sun Z., Sun X. 2008. Changes in biochemical characteristics related to firmness during fruit development of pepper (Capsicum annuиm L.). Europen J. Hort. Science 73 (4): 155-161.

Conforti F., Statti G.A., Menichini F. 2007. Chemical and biological variability of hot pepper fruits (Capsicum annuum var. acuminatum L.) in relation to maturity stage. Food Chem., 102: 1096-1104.[DOI:10. 1016/j.foodchem.2006.06.047]

De Guevara R.G.L., Pardo-Gonzalez J.E., Varon-Castellanos R., Navarro F.A. 1996. Evolution of color during the riprning of selected varieties of paprika pepper (Capsicum annuum L.). J. Agric. Food Chem. 44 (8): 2049 2052.

[DOI: 10.1021/jf950465m]

Duliński J., Leja M., Samotus B., Ścigalski A. 1988. Wybrane metody analizy materiałów roślinnych. AR Kraków, Skrypty dla szkół wyższych, 53-56. [in Polish]

Golcz A., Kozik E. 2004. Effect of several agrotechnical factors on vitamin C content in pepper (Capsicum annuum L.) and lettuce (Lactuca sativa L.). Rocz. AR Poznań. CCCLVI Ogrodn. 37: 67-74.

Howard L.R., Talcott S.T., Brenes C.H., Villalon B. 2000. Changes in phytochemical and antioxidant activity of selected pepper cultivars (Capsicum species) as influenced by maturity. J. Agric. Food Chem, 48: 17131720. [DOI: 10.1021/jf990916t]

Korenman S. 1973. Analiza fotometryczna. WNT, Warszawa. [in Polish]

Kosson R. 2003. Chlorophyll fluorescence and chilling injury of green pepper as affected by storage conditions. Acta Hort. 628: 379-385.

Kosson R., Stępowska A. 2002. Effect of cultivation method on yield and storage ability of sweet pepper. Folia Hort. 14/2: 69-76.

Kosson R., Stępowska A. 2005. The effect of equilibrium modified atmosphere packaging on quality and storage ability of sweet pepper fruits. Veg. Crops Res. Bull. 63: 139-149.

Kosson R., Stępowska A. 2006. The effect of perforated packaging on storage ability of green pepper fruits. Veg. Crops Res. Bull. 64: 1927.

Lee S.K., Kader A.A. 2000. Preharvest and postharvest factors influencing vitamin $\mathrm{C}$ content of horticultural crops. Postharvest Biol. Technol. 20: 207-220.

Leja M., Mareczek A., Rożek S., Wojciechowska R. 1998. Związki fenolowe jako biochemiczny wskaźnik pozbiorczego starzenia się warzyw. Zesz. Nauk. AR w Krakowie 333(57): 181-185. [in Polish]

Lisiewska Z., Kmiecik W. 1991a. Azotany i azotyny w warzywach. Cz. I. Wpływ różnych czynników na zawartość azotanów i azotynów w warzywach świeżych. Post. Nauk Roln. 3: 11-24. [in Polish]

Lisiewska Z., Kmiecik W. 1991b. Azotany i azotyny w warzywach. Cz. II. Zmiany zawartości azotanów i azotynów w warzywach podczas krótko i długoterminowego przechowywania. Post. Nauk Roln. 3: 25-31. [in Polish]

Madrid R., Navarro F., Collados I., Egea C., Alarcon A.L. 1999. Develop- 
ment of colour in red pepper fruits in soilless culture. J. Hort. Sci. Biotech. 74(2): 175-180.

Navarro J.M., Flores P., Garrido C., Martinez V. 2006. Changes in the contents of antioxidant compounds in pepper fruits at different ripening stages, as affected by salinity. Food Chem. 96: 66-73. [DOI:10.1016/ j.foodchem.2005.01.057]

Perucka I. 2004. Zmiany w zawartości karotenoidów w owocach papryki odmiany 'Bronowicka Ostra' zachodzące podczas dojrzewania i zastosowania etefonu. Acta Sci. Pol. Techno. Aliment. 3(1): 85-92. [in Polish]

Pilarski J., Kocurek M. 2005. The content of photosynthetic pigments and the lights conditions in the fruits and leaves of sweet pepper. Acta Physiol. Plant. 27 (2): 173-182.

Simonne A.H., Simonne E.H., Eitenmiller R.R., Mills H.A., Green N.R. 1997. Ascorbic acid and provitamin A contents in unusually colored bell pepper (Capsicum annuum L.). J. Food Comp. Anal. 10: 299-311.

Swain T., Hillis W.E. 1959. Phenolic constituents of Prunus domestica. I. Quantitative analysis of phenolic constituents. J. Sci. Food Agri. 10: 63-68.

Tadesse T., Hewett E.W., Nichols M.A., Fischer K.J. 2002. Changes in physicochemical attributes of sweet pepper cv. Domino during fruit growth and development. Sci. Hort. 93: $91-$ 103.

Wall M.M., Waddell C.A., Bosland P.W. 2001. Variation in $\beta$-carotene and total carotenoid content in fruits of Capsicum. HortScience, 36(4): 746749.

Wien H.C.(edit.) 1997. The physiology of vegetable crops. CAB International.

Yemm E.W., Wills A.J. 1954. The estimation of carbohydrates in plant extracts by anthrone. Biochem. J. 58: 508-514.

\section{WPŁYW FAZY DOJRZAŁOŚCI ORAZ KRÓTKOTRWAŁEGO PRZECHOWYWANIA NA JAKOŚĆ BIOLOGICZNĄ OWOCÓW PAPRYKI SŁODKIEJ}

\section{Streszczenie}

Paprykę słodką 'Spartacus' uprawiano w tunelu wysokim na wełnie mineralnej $\mathrm{z}$ wykorzystaniem systemu fertygacyjnego. Doświadczenie przeprowadzono w latach 2006-2008. Owoce papryki zbierano w trzech fazach dojrzałości: zielone, przebarwiające się oraz czerwone. W materiale roślinnym oznaczono zawartość kwasu askorbinowego, sumy fenoli, cukrów rozpuszczalnych, azotanów i jonów amonowych, a także azotu całkowitego, wolnych aminokwasów i suchej masy. Analizy przeprowadzono tuż po zbiorze owoców, a także po ich krótkotrwałym przechowywaniu.

W czerwonych owocach papryki oznaczono istotnie więcej kwasu askorbinowego, cukrów rozpuszczalnych i fenoli niż w owocach zielonych czy przebarwiających się. Zawartość azotanów była najwyższa w owocach zielonych i obniżała się $\mathrm{w}$ trakcie dojrzewania, podczas gdy zawartość jonów amonowych rosła w trakcie wybarwiania się owoców. Najniższym poziomem wolnych aminokwasów charakteryzowały się owoce zielone.

Owoce papryki przechowywano dwa tygodnie w temperaturze $5-8^{\circ} \mathrm{C}$, a następnie dwa dni w temperaturze pokojowej. Przechowywanie wpłynęło na obniżenie zawartości jonów azotanowych w zielonych i czerwonych owocach papryki. W trakcie przechowywania zwiększała się zawartość jonów amonowych, fenoli i cukrów rozpuszczalnych 
niezależnie od stopnia dojrzałości. W przypadku owoców przebarwiających się i czerwonych obserwowano wzrost zawartości kwasu askorbinowego w trakcie przechowywania. Nie notowano natomiast zmian w zawartości suchej masy w owocach papryki. Wartość biologiczna papryki była zależna od fazy dojrzałości owoców w momencie zbioru, podczas gdy w trakcie przechowywania notowano podobne zmiany składników niezależnie od fazy dojrzałości. 